\title{
O NIEPOLĄCZALNOŚCI RÓL PROCESOWYCH ORGANÓW JEDNOSTEK SAMORZĄDU TERYTORIALNEGO
}

\section{ZŁOŻONOŚĆ UKŁADU INTERESÓW W POSTĘPOWANIU ADMINISTRACYJNYM}

W nauce prawa i postępowania administracyjnego tradycyjnie operuje się, przynajmniej na poziomie ogólnych rozważań teoretycznych, prostym schematem odzwierciedlającym rozłączność ról procesowych podmiotów uczestniczących w jakikolwiek sposób w czynnościach zmierzających do załatwienia sprawy albo tylko umocowanych (legitymowanych) do udziału w nich. Wyróżnia się zatem zawsze organ prowadzący postępowanie jako gospodarza procesu oraz stronę lub strony postępowania. Poza nimi przepisy prawa stwarzaja podstawę do partycypacji w postępowaniu innych podmiotów. Są nimi w szczególności organy zajmujące stanowisko w trybie współdziałania oraz podmioty na prawach strony. Ten czytelny i przyjmowany do niedawna bez zastrzeżeń podział skomplikował się nieco za sprawą rozwoju różnych koncepcji stakeholders, zakładających potrzebę dopuszczenia do postępowania w odpowiednich formach podmiotów, które mogą być dotknięte skutkami rozstrzygnięcia, bądź zainteresowanych wynikiem działań z innych powodów. Idea ta, korespondująca z kluczowym założeniem postępowań typu notice-and-comment, stała się także źródłem inspiracji do poczynań prawodawcy związanych z regulacją postępowań jurysdykcyjnych. Doskonałą ilustracją sformułowanej tezy sa pojawiajace się $\mathrm{w}$ naszym ustawodawstwie przepisy mające chronić interesy faktyczne jednostki ${ }^{1}$.

Używając pojęcia stakeholders, uznaje się istnienie stosownej dywersyfikacji preferencji, celów i interesów oznaczanych w ten sposób podmiotów: poszczególnych jednostek, środowisk i społeczności lokalnych, organizacji

${ }^{1}$ Tą intencją kierowano się, ustalając redakcję chociażby nieobowiązującego już art. 15 ust. 2 ustawy z 18 lipca 2001 r. - Prawo wodne (t.jedn.: Dz. U. 2017, poz. 1121, utraciła moc - Dz. U. 2017, poz. 1566). Przewidział on wszczęcie postępowania w przedmiocie ustalenia linii brzegu dla cieków naturalnych, jezior i innych naturalnych zbiorników wodnych nie tylko na wniosek podmiotu dysponującego w sprawie interesem prawnym, lecz również interesem faktycznym. Podobnie trzeba ocenić nakaz uwzględniania przez organy administracji interesów osób trzecich, na które wynik postępowania ma bezpośredni wpływ, w trybie art. 7a § 1 in fine i art. 81a § 2 pkt 1 in fine ustawy z 14 czerwca 1960 r. - Kodeks postępowania administracyjnego, t.jedn.: - Dz. U. 2018, poz. 2096 ze zm. (dalej jako: k.p.a. lub kodeks). 
pozarządowych, sektora prywatnego oraz władzy publicznej. W publikacjach naukowych można nawet spotkać się z określeniem multi-stakeholders i komplementarnymi wobec niego terminami: multi-stakeholder-processing/multi-stakeholder processes for governance, multiple viewpoints of different stakeholders oraz multi-stakeholder dialogues and partnerships ${ }^{2}$. Identyfikacja wskazanych pojęć i - co się z tym łączy - wyodrębnienie aktorów pierwszoi drugoplanowych oraz pozostałych, a z drugiej strony - tych, którzy wspieraja dane przedsięwzięcie lub są jemu przeciwni, pozwala wypracować adekwatny do sytuacji sposób działania. W klasycznej teorii przedsiębiorstw, a w konsekwencji - teorii governance, w ramach kategorii stakeholders wyróżnia się jeszcze grupę podmiotów mających bezpośredni wpływ na bieg spraw (głos decydujacy), traktowanych jako udziałowcy albo legitymowani do udziału w ukształtowaniu pewnego rozwiązania, czyli shareholders. Nie oznacza to oczywiście, że zapatrywania innych podmiotów sa pomijane lub deprecjonowane na etapie dochodzenia do pożądanego rezultatu ${ }^{3}$.

Zaprezentowane spostrzeżenia prowadzą do wniosku, że realizowane współcześnie zasady wypełniania zadań publicznych, uwarunkowane m.in. chęcia zapewnienia ekonomicznej efektywności oraz optymalnej alokacji zasobów i środków pozostających w dyspozycji państwa, wyłamują się z tradycyjnych, stworzonych przed laty z myślą o ochronie praw podmiotowych, konstrukcji prawa procesowego ${ }^{4}$. Pojęcie strony postępowania administracyjnego i podmiotów na prawach strony już nie wystarcza dla uformowania proceduralnych mechanizmów wyważania wszystkich, uwikłanych w pewna sprawę interesów. Samo zdefiniowanie relacji pomiędzy nimi i ustalenie ich prawnej kwalifikacji oraz sprecyzowanie ról procesowych odgrywanych przez poszczególnych „aktorów”, zwłaszcza w układzie zależności: organ prowadzący postępowanie - strona, nastręcza w wielu przypadkach niemało trudności ${ }^{5}$. Równie poważne dylematy wyłaniają się na tle analizy innego rodzaju związków, których istotę da się przedstawić, stawiając pytanie: czy organ upoważniony do wydania aktu współdziałania w trybie art. 106 k.p.a. (samorządu zawodowego, taki jak izba aptekarska lub notarialna) może być jednocześnie

2 Zob. Priddat (2008): 352 n.; Pollitt, Bouckaert (2011): 220, oraz Hemmati et al. (2002): $1 \mathrm{n}$. Co do definicji słowa „stakeholders” zob. Supernat (2005): 515-516, oraz Garner (2009): 1534.

${ }^{3}$ Kmieciak (2017a): 29-30.

4 Według O. Bähra całość prawa publicznego, w szczególności zaś prawa administracyjnego, miała zostać zmodernizowana przez odwołanie się do pojęć i koncepcji prawa prywatnego oraz procedury cywilnej. Autor postrzegał państwo jako część społeczeństwa, wyrażając przekonanie, że tak jak jednostka powinno ono podlegać jurysdykcji sądów powszechnych. Stworzoną przez niego teorię rozwinął O. Mayer, głosząc pogląd, że urzeczywistnienie idei państwa prawnego może nastapić tylko w razie przyjęcia za jego podstawę konstrukcji publicznych praw podmiotowych, określającej stosunki w obrębie prawa publicznego - por. wywody Zoller (2008): 80-81, oraz Künnecke (2007): $22 \mathrm{n}$.

5 Pojęcie „aktorzy postępowania” utrwalone w obcym piśmiennictwie zdaje się lepiej ukazywać różnorodność pełnionych przez nie ról niż słowo „podmioty”, którym posługują się polscy autorzy. Używane jest ono również w rozmaitych kontekstach, np. Blake (2011: 244) pisze o wnioskodawcy (stronie) nadużywającym swoich praw procesowych jako „złym aktorze” (applicant is a bad actor). 
strona postępowania? ${ }^{6}$ Tymczasem prowadzone w rodzimej literaturze dociekania nadal zdominowane są dokonanymi niegdyś, wywodzącymi się po części z innej epoki ustaleniami. Z tych względów oraz z racji dynamicznie zmieniającej się rzeczywistości społecznej nie zawsze łatwo uchwytna jest właściwa dla sfery prawa administracyjnego dystynkcja: interes indywidualny - interes społeczny (publiczny, ogólny). Wymownie potwierdzają to np. głosy tych autorów, którzy a priori sytuują organizację społeczną występująca jako podmiot na prawach strony $\mathrm{w}$ postępowaniu administracyjnym $\mathrm{w}$ roli przedstawiciela interesu społecznego. Okoliczność, że przepis art. 31 § 1 in fine k.p.a. uzależnia udział takiej organizacji w postępowaniu od uprzedniego zbadania przez organ administracji, czy przemawia za tym interes społeczny, nie przesądza bynajmniej o racjach, których może ona bronić. Nie sposób sprowadzać ich wyłącznie do korzyści rozpatrywanych przez pryzmat interesu ogólnego lub indywidualnego. Mogą one także mieścić się w obrębie kategorii pośredniej, oznaczonej przez Giampaolo Rossiego zwrotem „interesy ponadjednostkowe” (interessi sovraindividuali), będącym synonimem określenia: interesy zbiorowości (interessi difussi)7. Jako pojęcie zbiorcze obejmuje ono wszakże podlegające dalszej konkretyzacji interesy. Da się wśród nich wyróżnić interesy rozmaitych grup społecznych i wspólnot terytorialnych (według Rossiego - interessi collettivi, di collettività territoriali) oraz właściwe interesy zbiorowości, których znaczenie najlepiej zdaja się oddawać wyrażenia: mieszane albo złożone. Ich istota jest to, że są one wspólne dla całości grupy i jej poszczególnych członków ${ }^{8}$. Tak pojmowane interesy różnią się od interesów grupowych tym, że dotyczą nieokreślonej bliżej liczby osób (un numero potenzialmente indefinito di sogetti sono interessi diffusi). Nie tworzą one homogenicznej struktury ani tym bardziej zorganizowanego wedle jakichś przejrzystych reguł systemu. Przeciwnie, cechą takiej zbiorowości jest pluralizm poglądów, postaw i celów, a jej sytuację zwięźle określają słowa - „stan płynny” (allo stato fluido) ${ }^{9}$. Nie ulega jednak wątpliwości, że prawo musi poszukiwać form artykułowania również tego typu oczekiwań, aspiracji i dążeń.

\section{PROCESOWE KONSEKWENCJE DUALNEGO STATUSU ORGANÓW JEDNOSTEK SAMORZĄDU TERYTORIALNEGO}

Reaktywowanie w Polsce w 1990 r. samorządu terytorialnego zrodziło konieczność dostosowania przepisów kodeksu o wyłączeniu pracownika oraz organu (rozdział 5 działu I) do nowej formuły wypełniania zadań publicznych w formach jurysdykcyjnych. Znacznąich część przejęły wówczas organy gmin -

${ }^{6}$ Zob. Kmieciak (1994): 242-243; (2016): 125 n.

${ }^{7}$ Zob. Rossi (2011): 75

${ }^{8}$ Lemetre, Miranda (2011): 205-206.

${ }^{9}$ Lemetre, Miranda (2011): 205. Z uwagami tymi korespondują rozważania Iwańskiej (2013): 306-307, 326 n. oraz 342 n., dotyczące „odindywidualizowania” ochrony prawnej realizowanej w formie „prawnośrodowiskowej skargi zbiorowej”; szerzej Kmieciak (2017b): 31-33. 
wójtowie, burmistrzowie i prezydenci miast. Sa oni organami wykonawczymi podstawowych jednostek samorządu terytorialnego, mających osobowość prawną i dysponujacych prawem własności oraz innymi prawami majątkowymi. Wypełniaja zatem funkcje kojarzone ze sfera dominium - korzystania z praw i wykonywania obowiązków, których korelatem jest pojęcie interesu prawnego w rozumieniu art. 28 k.p.a. Organy te, niejako równolegle, realizuja zgoła odmienną funkcję, właściwa dla sfery imperium, co wynika z faktu ustawowego określenia ich kompetencji. Jan Zimmermann nie wahał się napisać, że organy te, „choć nie są "stronami«, uczestniczą merytorycznie w postępowaniu"10. Jednak uczestniczą jako kto? Odpowiedź nie nastręcza większych trudności: jako uosobienie władzy publicznej - podmiot usytuowany w jednym z segmentów owej władzy, poza obszarem dominium. Rozłączność tych dwóch ról nie podlega - jak sądzę - żadnej dyskusji ${ }^{11}$.

Tym założeniem kierował się prawodawca, nowelizując w 1990 r. k.p.a. Ustawą z 24 maja 1990 r. o zmianie ustawy - Kodeks postępowania administracyjnego ${ }^{12}$ dodano do kodeksu przepis oznaczony jako art. 27a. Stanowił on o wyłączeniu organów gminy „od załatwiania spraw, w której stroną jest gmina”. W takim przypadku legitymowany do załatwienia sprawy stawał się organ innej gminy, wyznaczony odpowiednio przez kolegium odwoławcze przy sejmiku (w sprawach należących do zadań własnych gmin) albo wojewodę (w sprawach należących do zadań zleconych z zakresu administracji rządowej). Rozwiązanie, o którym mowa, mające chronić wartości w postaci bezstronności orzekania w postępowaniu administracyjnym oraz samodzielności gmin (odrębność ich prawnego bytu), nie przetrwało zbyt długo. Zamieszanie wywołane podjęciem przez Trybunał Konstytucyjny (TK) uchwały z 23 czerwca 1993 r. (W 3/92) ${ }^{13}$ skłoniło ustawodawcę do uchylenia art. 27a kodeksu ${ }^{14}$. Wyciagną on - ulegając perswazji niektórych przedstawicieli doktryny oraz środowiska samorządowego - zbyt pochopne wnioski z wyrażonej przez Trybunał tezy, że „organy gminy podlegają na podstawie art. 27a k.p.a. wyłączeniu od załatwienia sprawy rozstrzyganej w formie decyzji administracyjnej, jeżeli przedmiotem sprawy jest stosunek cywilnoprawny, którego stronąjest gmina". Krytyka, z którą spotkało się stanowisko TK, nie stwarzała podstaw do takiej reakcji. Powinna ona raczej być traktowana jako dogodny punkt wyjścia dyskusji na temat poszukiwania optymalnej formuły zespolenia zespołu standardów uchodzących za podstawowy atrybut rzetelnego procesu (bezstronności/ obiektywizmu orzekającego $\mathrm{w}$ sprawie organu ${ }^{15} \mathrm{z}$ instytucjami prawa ustrojowego. Opisany zabieg można określić mianem zawoalowanej albo pośredniej

10 Zimmermann (2017): 111.

11 Por. też argumentację Kmieciaka (2017a): 75-78, odnoszącą się do sytuacji ujętej à rebours, tj. procesowej pozycji organu administracji rządowej - dyrektora regionalnego zarządu gospodarki wodnej, uznanego przez Sąd jednocześnie za organ umocowany do załatwienia sprawy i reprezentanta strony postępowania administracyjnego.

12 Dz. U. Nr 34, poz. 201.

13 OTK 1993, nr 3, poz. 46.

14 Przepis ten, z mocy art. 25 pkt 3 ustawy z 12 października 1994 r. o samorządowych kolegiach odwoławczych (Dz. U. Nr 122, poz. 593), utracił moc z dniem 6 grudnia 1994 r.

15 Co do tej wartości - zob. Suwaj (2004): 13 n. 
(moca przepisu ustawowego) derogacji wykładni dokonanej przez Trybunał ${ }^{16}$. Jego konsekwencje okazały się bardziej poważne i dalekosiężne, niż można było przypuszczać.

Brak gwarancji, którą na krótki czas ustanowił art. 27a, przy wasko zakreślonych przez art. 25 k.p.a. przesłankach wyłączenia organu administracji od załatwienia sprawy ${ }^{17}$, doprowadził do upowszechnienia się w obrębie samorządu terytorialnego praktyki łacczenia w jednej osobie ról procesowych właściwych dla obszaru dominium i imperium. Jest ono widoczne np. w sprawach lokalizacji inwestycji celu publicznego, podlegających załatwieniu według reżimu przepisów art. 50-58 ustawy z 27 marca 2003 r. o planowaniu i zagospodarowaniu przestrzennym ${ }^{18}$. Występując z wnioskami jako inwestor (przedstawiciel strony postępowania), wójtowie, burmistrzowie albo prezydenci zwykli rozpatrywać je w zakresie swojej właściwości, wchodząc w rolę organu prowadzacego postępowanie. Granica pomiędzy tym, kto rozstrzyga i kto o coś zabiega, zaciera się, wywołując mimowolnie pytania o logikę takiego rozwiązania. Czy daje się ono pogodzić z paremia, że nie można być sędzią we własnej sprawie? O niebezpieczeństwie zespolenia dwóch ról procesowych w ręku jednego podmiotu nie zawsze możemy przekonać się, analizując wyłącznie przepisy prawa materialnego, legitymujące do złożenia wniosku i kreujace umocowanie do podjęcia rozstrzygnięcia. Niekiedy trzeba jeszcze uwzględnić inne uregulowania, w szczególności prawa ustrojowego. Jest tak chociażby w sprawach załatwianych decyzjami wydawanymi w trybie art. 11a ustawy z 10 kwietnia 2003 r. o szczególnych zasadach przygotowania i realizacji inwestycji w zakresie dróg publicznych ${ }^{19}$. Zgodnie z jego ust. 1, w odniesieniu do dróg powiatowych i gminnych, decyzję o zezwoleniu na realizację inwestycji drogowej na wniosek właściwego zarządcy drogi (którym może być organ gminy) wydaje wykonujący zadania zlecone z zakresu administracji rządowej starosta. Jednak w przypadku pewnej kategorii jednostek samorządowych miast na prawach powiatu to ich prezydenci pełnią funkcje starosty ${ }^{20}$. Według utartej już praktyki rozpatrują oni składane przez siebie wnioski, jak można mniemać - z pozytywnym wynikiem. Jak trafnie wywodzi Marek Szewczyk, żaden inny podmiot nie może skorzystać z dobrodziejstw płynących z uregulowań tej ustawy, jak tylko organy administracji drogowej (w tym wójtowie, burmistrzowie i prezydenci miast). Inne podmioty moga natomiast zostać dotknięte ich skutkami ${ }^{21}$.

Stanowisko doktryny w analizowanej materii razi niekonsekwencja. Niektórzy jej przedstawiciele uznali za dopuszczalne prowadzenie przez organ

16 Szerzej Chróścielewski (2019): 211, 219-220.

17 Mimo przeprowadzanych ustawicznie, przekraczających rozsądną miarę, nowelizacji kodeksu redakcja tego przepisu nie zmieniła się od czasu jego ustanowienia w całkowicie odmiennych warunkach prawnoustrojowych.

18 T.jedn.: Dz. U. 2020, poz. 293.

19 T.jedn.: Dz. U. 2018, poz. 1474.

20 Zob. art. 92 ust. 1 pkt 2 ustawy z 5 czerwca 1998 r. o samorządzie powiatowym (t.jedn.: Dz. U. 2020, poz. 920).

${ }^{21}$ Szewczyk (2020): 85. 
gminy postępowania w sprawie, w której jest ona strona ${ }^{22}$. Prezentowany jest również pogląd, że w takiej sytuacji gmina ma prawo uczestniczyć w postępowaniu przed organem drugiej instancji, a nawet wnieść skargę do sądu administracyjnego na wydana w postępowaniu odwoławczym decyzję ${ }^{23}$. Według bardziej wyważonej opinii po uchyleniu art. 27a k.p.a. „upada stosowanie instytucji wyłączenia organu, ale moga zachodzić podstawy do wyłączenia wszystkich pracowników urzędu gminy, łącznie z jego kierownikiem [...] $\mathrm{z}$ racji pozostawania $\mathrm{w}$ takim stosunku prawnym $\mathrm{z}$ gmina, który wpływa na prawa i obowiązki pracowników, a to z tytułu treści obowiązków pracowniczych spoczywających na pracownikach samorządowych”. Głoszący to zapatrywanie Janusz Borkowski dodał, że problem ten może powstać także wtedy, „gdy stroną będzie powiat lub województwo jako samodzielna wspólnota samorządowa"24. Autor wyraźnie nawiązał do wyrażonej w wielu publikacjach koncepcji Wojciecha Chróścielewskiego, nieukrywającego, że z punktu widzenia wymagań prawdy obiektywnej nie sposób wyobrazić sobie prowadzenia postępowania administracyjnego „przez organy gminy wobec gminy będącej stroną tego postępowania [...] na takich samych zasadach jak postępowanie prowadzone wobec innych podmiotów”. W jego ocenie trzeba przyjąć, że organy gminy i pozostałych jednostek samorządu terytorialnego „podlegaja, mimo uchylenia art. 27a, wyłączeniu od załatwienia sprawy, której strona jest dana jednostka samorządu", a jego podstawą jest art. $24 \S 1$ pkt 1 kodeksu ${ }^{25}$. Teza ta spotkała się z aprobatą m.in. Romana Hausera i Marka Szewczyka ${ }^{26}$, Andrzeja Wróbla ${ }^{27}$ i Piotra Przybysza ${ }^{28}$. Można również wskazać opracowania naukowe, których autorzy unikają zajęcia stanowiska w tej kwestii, poprzestając na zrelacjonowaniu osnowy trwającego już wiele lat sporu ${ }^{29}$.

\section{PRÓBY ROZWIĄZANIA PROBLEMU W RAMACH DZIAŁALNOŚCI ORZECZNICZEJ SĄDÓW ADMINISTRACYJNYCH}

Zdecydowanie bardziej urozmaicone - choć nie zawsze klarowne i dogłębnie uzasadnione - stanowisko w przedmiocie dopuszczalności prowadzenia przez organy jednostek samorządu terytorialnego postępowania w sprawach, w których posiadają one przymiot strony (dysponuja interesem prawnym), prezentują sądy administracyjne. Od pewnego czasu można zaobserwować wyraźna tendencję do negowania tradycyjnych zapatrywań na temat odno-

\footnotetext{
22 Tak Klat-Wertelecka (2000): 138.

${ }^{23}$ Kubalski (2008): 72.

24 Borkowski (2019): 198.

${ }^{25}$ Chróścielewski (2019): 211-212.

${ }^{26}$ Hauser, Szewczyk (1996): 45.

27 Wróbel (2018): 261.

28 Przybysz (2017): 133.

29 Tak m.in. Klonowski (2015): 177; Knysiak-Sudyka (2017): 177-179.
} 
szącej się do takich przypadków gwarancji realizacji, ujętej obecnie wprost w art. $8 \S 1$ kodeksu zasady bezstronności, wyrażonych m.in. w uchwale Naczelnego Sądu Administracyjnego z 19 maja 2003 r. (OPS 1/03) ${ }^{30}$. Stwierdzono w niej, że w sprawie dotyczącej zwrotu wywłaszczonej nieruchomości będącej własnością miasta na prawach powiatu ,prezydent tego miasta jako organ wykonawczy miasta i reprezentujacy je na zewnątrz oraz także jako pracownik urzędu miasta, a jednocześnie sprawujący funkcję starosty, podlega wyłączeniu na podstawie art. $24 \S 1$ pkt 1 i 4 k.p.a., co w konsekwencji wyłącza możliwość upoważnienia przez niego do załatwienia sprawy jego zastępców i pozostałych pracowników urzędu miasta”. Zbieżna z tymi ustaleniami konstatacja znalazła się w wyroku Sądu Najwyższego z 7 czerwca 2001 r. (III RN 104/00) ${ }^{31}$.

W odmiennym kierunku poszła argumentacja, którą posłużono się w wyroku Wojewódzkiego Sądu Administracyjnego w Krakowie z 22 marca 2018 r. (II SA/Kr 185/18) ${ }^{32}$. Przyjęto w nim, że sfery władztwa administracyjnego i dominium często w sposób zamierzony łączone są ze soba, „co wynika ze specyfiki postępowania administracyjnego. Fakt, iż w stosunku do składnika majątkowego czy prawa należącego do jednostki, która jednocześnie jest organem administracji, inne podmioty formują wnioski, żądania czy roszczenia inicjujące wszczęcie postępowania administracyjnego, sam w sobie nie przesądza, iż organ ten wyłaczony jest z orzekania w sprawie tego wniosku czy roszczenia”. Wyłączenia takiego nie sposób również - zdaniem Sądu - zakładać z góry wówczas, kiedy „organ orzekający jest jednocześnie inicjatorem postępowania. W szczególności w obowiąującym porządku prawnym nie ma ogólnej regulacji uprawniającej do wyłączenia organu samorządu terytorialnego w sytuacji, gdy sprawa będąca przedmiotem postępowania administracyjnego pozostaje w związku z interesem prawnym danej wspólnoty samorządowej”. W wyroku tego Sądu z 22 czerwca 2018 r. (II SA/Kr 374/18) ${ }^{33}$ zauważono natomiast, że co do zasady „nie ma alternatywy w sytuacji, gdy inwestorem zamierzenia inwestycyjnego jest gmina a podmiotem inicjujacym postępowanie o ustalenie warunków zabudowy jest wójt, burmistrz lub prezydent miasta. W takiej sytuacji wójt, burmistrz lub prezydent miasta prowadzi to postępowanie i wydaje decyzję w I instancji”.

W wielu orzeczeniach nawiązuje się bezpośrednio do faktu utraty mocy obowiązującej przez art. 27a k.p.a. Przykładowo w wyroku Naczelnego Sądu Administracyjnego z 1 kwietnia 2009 r. (II OSK 460/08) ${ }^{34}$ zaznaczono, że nie ma „wyraźnej normy, wzorem uchylonego art. 27a k.p.a., wyłączającej wójta, burmistrza (prezydenta miasta) od orzekania w sprawie, w której jego gmina jest stroną". Obowiązku takiego nie można - w przekonaniu Sądu - dopatrzyć się „w regulacjach art. 24".

\footnotetext{
30 Orzecznictwo Naczelnego Sądu Administracyjnego 2003, nr 4, poz. 115.

31 Orzecznictwo Sądów Polskich 2002, nr 10, poz. 133.

32 Lex nr 2470522.

33 Lex nr 2513878.

34 Lex nr 562860.
} 
W opisanym nurcie wypowiedzi mieszczą się spostrzeżenia zawarte w wyroku Wojewódzkiego Sądu Administracyjnego w Kielcach z 15 listopada 2017 r. (II SA/Ke 654/17) ${ }^{35}$. Nadano im postać następujących tez:

1. Przepisy u.p.z.p. wyraźnie wprowadzają kompetencję prezydenta miasta (wójta, burmistrza) do wydawania decyzji o warunkach zabudowy (poza terenami zamkniętymi). Jednocześnie brak jest wyraźnego wyłączenia tej kompetencji w przepisach szczególnych. Kompetencja prezydenta miasta (wójta, burmistrza), co do zasady, nie ulega wyłączeniu w sytuacji, gdy wydana decyzja może mieć wpływ na interes prawny gminy. Prezydent miasta w takiej sytuacji reprezentuje przede wszystkim interes wspólnoty samorządowej i działa dla dobra wspólnego.

2. Przepisy regulujące kompetencje organów do wydania decyzji administracyjnej muszą być rozumiane ściśle, zatem brak jest podstaw prawnych do przyjęcia w drodze wykładni sądowej tych przepisów, że dany organ jest wyłączony od rozpatrywania określonej kategorii spraw. W przeciwnym wypadku mogłoby dojść do naruszenia przepisów o właściwości miejscowej.

3. Nie można skutecznie twierdzić, że dochodzi do naruszenia prawa w sprawie, gdy prezydent miasta wydaje decyzję, rozstrzygając przy tym o prawach i obowiązkach jednostki samorządu terytorialnego (gminy), którą reprezentuje.

Niestety, Sąd nie wyjaśnił, czy troska o „interes wspólnoty samorządowej” i działanie „dla dobra wspólnego” zyskują prymat nad obiektywnym, zgodnym z przepisami prawa rozstrzygnięciem sprawy. Nie zastanowił się on także nad tym, czy pojęcia kompetencji i interesu prawnego nie sa aby kategoriami rozłącznymi. Nie dostrzegł wreszcie tego, że przyznanie danemu organowi kompetencji (wyznaczenie przez prawo jego właściwości w sprawie) nie oznacza automatycznie posiadania zdolności do prowadzenia postępowania, gdyż granice tej ostatniej wytyczają przepisy o wyłączeniu.

Równie osobliwy pogląd sformułowano w wyroku Naczelnego Sądu Administracyjnego z 30 marca 2010 r. (II OSK 88/10) ${ }^{36}$. Zwrócono w nim uwagę, że jeśli przepis prawa powierza organowi administracji kompetencję do podjęcia decyzji i stwarza podstawę do wystapienia z wnioskiem o wszczęcie postępowania, jest ono uruchamiane z urzędu. Połączenie ról procesowych organu orzekającego w sprawie i wnioskodawcy zostało tym samym zinterpretowane przez Sąd jako okoliczność kwalifikująca do zmiany formuły postępowania na prowadzone ex officio.

Trudno oprzeć się wrażeniu, że w niektórych orzeczeniach sądowych najwyraźniej mylona jest kolejność ustaleń co do konstrukcji prawa materialnego legitymujących do udziału w postępowaniu w jednej z przewidzianych kodeksem ról procesowych. Tego rodzaju błędu nie ustrzegł się Naczelny Sąd Administracyjny w uchwale składu 7 sędziów z 16 lutego 2016 r. (I OPS 2/15) ${ }^{37}$. Zgodnie z nia: „Powiat nie ma legitymacji procesowej strony w sprawie o ustalenie odszkodowania od powiatu za nieruchomość przejęta pod drogę publiczną, która stała się własnością powiatu, jeżeli decyzję wydaje starosta na pod-

${ }^{35}$ Lex nr 2411782.

36 Lex nr 597931.

37 Orzecznictwo Naczelnego Sądu Administracyjnego i Wojewódzkich Sądów Administracyjnych 2016, nr 4, poz. 54 . 
stawie art. 12 ust. $4 \mathrm{a}$ w związku z art. 11a ust. 1 ustawy z dnia 10 kwietnia 2003 r. o szczególnych zasadach przygotowania i realizacji inwestycji w zakresie dróg publicznych (Dz.U. 2013 r. poz. 687 ze zm.) oraz art. 38 ust. 1 ustawy z dnia 5 czerwca 1998 r. o samorządzie powiatowym (Dz.U. z 2015 r. poz. 1445)". Rzecz w tym, że w rozważanej sytuacji to starosta powinien zostać wyłączony od załatwienia sprawy, skoro dotyczyła ona interesu prawnego powiatu, czyli podmiotu „legitymowanego pierwotnie” (majacego prawo do zainicjowania postępowania przed właściwym organem administracji publicznej i uczestnictwa w nim). Punkt widzenia Naczelnego Sądu Administracyjnego podzielił Wojewódzki Sąd Administracyjny w Rzeszowie w wyroku z 11 kwietnia 2018 r. (II SA/Rz 1393/17) ${ }^{38}$.

\section{USTROJOWY CHARAKTER ZASADY BEZSTRONNOŚCI ORGANU PROWADZAC_EGO POSTĘPOWANIE TYPU JURYSDYKCYJNEGO}

Podejmowane - w ramach drugiego z omówionych nurtów orzecznictwa próby rozwiązania problemu niemal całkowicie ignorują wnioski płynące z faktu objęcia działalności jurysdykcyjnej organów jednostek samorządu terytorialnego ogólnym reżimem prawa procesowego - tym samym dla całej administracji publicznej. Bezstronność i obiektywizm orzekania sa standardem mocno zakotwiczonym w idei rządów prawa, wartością o wymiarze konstytucyjnym, której źródeł można też doszukać się w postanowieniach konwencyjnych. Rozważajac znaczenie tej zasady i jej zwiąek z innymi standardami postępowania administracyjnego, Tanja Maier nie wahała się przyznać, że stanowi ona „dobro wspólne europejskiej tradycji prawnej” (gemeinsames Gut europäischer Rechtstradition) ${ }^{39}$.

W systemach common law wartość tę kojarzy się z jednym z wymagań natural justice, czyli reguł wynikajacych z naturalnego poczucia sprawiedliwości. Przeciwdziałanie stronniczości (the rule against bias) ma tam umożliwić realizację prawa strony do rzetelnego wysłuchania. Jak podkreśla się w literaturze, ze swojej istoty powinno ono być wysłuchaniem bezstronnym (a fair hearing must be an unbiased hearing) ${ }^{40}$. W orzecznictwie sądów amerykańskich bezstronność podmiotu podejmujaccego decyzję uznawana jest z kolei za esencjonalny składnik konstytucyjnej klauzuli due proces ${ }^{41}$. Potrzeba dochowania tego wymagania w trakcie postępowania przed organami administracji publicznej nie jest także kwestionowana w systemach prawa kontynentalnego. W niektórych z nich jego respektowanie łączy się wyraźnie z zakorzeniona $\mathrm{w}$ tradycji prawa francuskiego koncepcją droits de la défense, będącą de facto

\footnotetext{
38 Lex nr 2494627.

39 Maier (2001): 260.

40 Wade, Forsyth (2009): 402; podobnie Carroll (2002): 297.

${ }^{41}$ Gellhorn, Levin (2006): 237.
} 
odmianą wyróżnionej doktryny „prawa do rzetelnego wysłuchania” ${ }^{2}$. Nie brak także opinii, że bezstronność - jak process value - jest rdzeniem rozwijanej w orzecznictwie sądowym, także poza Europa, doktryny sprawiedliwości proceduralnej (procedural fairness) ${ }^{43}$. Co istotne, w rozważaniach na ten temat nie różnicuje się specjalnie pozycji sądów i innych organów wypełniajacych funkcje jurysdykcyjne, usytuowanych $\mathrm{w}$ obrębie władzy wykonawczej ${ }^{44}$. Te dwie grupy podmiotów traktowane są nawet niekiedy jako jedność w sensie instytucjonalnym, wobec których powinny obowiązywać te same gwarancje ochrony bezstronności i obiektywizmu orzekania. W odniesieniu do organów administracji publicznej akcentowany jest - co prawda - obowiąek troski o poszanowanie interesu ogólnego, który jednak nie jest pojmowany jako przeszkoda do realizacji utrwalonych w tradycji danego systemu zasad rzetelnego postępowania. Przeciwnie, w ustawodawstwie wielu państw można doszukać się przepisów formułujących powinność działania bez uszczerbku dla każdej ze wskazanych wartości, tak aby zapewnić ich względną równowagę i respektowanie w możliwie najszerszym zakresie.

Nie najgorszą ilustracją przedstawionego twierdzenia jest art. $4 \mathrm{f}$ ustawy boliwijskiej nr 2341 z 23 kwietnia 2002 r. o postępowaniu administracyjnym, który nakazując przestrzeganie zasady bezstronności (principio de imparcialidad), zobowiązał administrację do ochrony interesu ogólnego (defensa del interés general) oraz unikania zachowań, które prowadziłyby do dyskryminacyjnego bądź zróżnicowanego traktowania administrowanych ${ }^{45}$. Trzeba zarazem zaznaczyć, że ocena, czy pewne działanie leży w interesie publicznym (społecznym, państwowym, wspólnoty lokalnej albo nieokreślonej bliżej zbiorowości), musi odbywać się zawsze w granicach obowiązującego prawa, w szczególności w toku ustaleń dokonywanych dla celów stosowania przepisów zawierających zwroty nieostre. Wraz z ogólnymi klauzulami kodeksowymi (takimi jak zawarte w art. $7,7 \mathrm{a}, 8 \S 1,74 \S 1$, 81a, 137 albo $154 \S 1$ i 155) tworza one podstawę do prawnej kategoryzacji i wyważania różnych interesów. Właściwościa tego rodzaju zwrotów normatywnych jest - co wyczerpująco uzasadnił swego czasu Mirosław Wyrzykowski - uzyskiwanie treściowych konturów dopiero $\mathrm{w}$ rezultacie zastosowania ich do konkretnych przypadków. Utożsamiane z nimi pojęcia nieostre nie maja „przed zastosowaniem [...] konkretnej treści, ich zawartość treściowa rzadko może zostać zdefiniowana, a na ogół może być jedynie przedmiotem opisu ich cech zasadniczych" ${ }^{46}$. Wykładnia obowiazującego prawa jest zatem tym narzędziem, które pozwala na harmonizowanie ogólnych, wiążących administrację zasad rangi konstytucyjnej, konwencyjnej lub ustawowej, przy jednoczesnym zachowaniu ugruntowanej w poszczególnych systemach prawnych hierarchii wyprowadzanych z nich dyrektyw ${ }^{47}$.

\footnotetext{
42 Schwarze (2010): $1243 \mathrm{n}$.

${ }^{43}$ Co do tego pojęcia zob. Kmieciak (2014): 95-101.

${ }^{44}$ Kmieciak (2011): $177 \mathrm{n}$.

45 Zob. Brewer-Carias (2009): 171.

46 Wyrzykowski (1986): 50.

${ }^{47}$ Kmieciak (2014): 137-139.
} 
Bez ryzyka popełnienia błędu można powiedzieć, że zasada bezstronności organów prowadzących wszelkie postępowania typu jurysdykcyjnego, bez względu na układ reprezentowanych w konkretnej sprawie interesów, ma wymiar uniwersalny. Jest ona - w rozumieniu naszych pojęć - zasadą ustrojowa, wynikajaccą z konstytucyjnych wymagań demokratycznego państwa prawnego, której stosowanie nie może być wyłączone moca innych zasad, z powołaniem się na wątpliwe metodologicznie założenia. Nie do przyjęcia jest w szczególności teza, że odstępstwa od niej można uzasadnić przyczynami uchodzacymi za pragmatyczne, takimi jak konieczność dochowania przepisów o właściwości organów jednostek samorządu terytorialnego albo utratą mocy przez przepisy regulujące niegdyśs wprost kwestię jednego z elementów wyłączenia tych organów od załatwienia sprawy. Jak starałem się wykazać, operowanie tego typu argumentacja stwarza tylko pozory odniesienia się do istoty problemu, przesłaniając rzeczywiste, prawne tło wyłaniających się kontrowersji.

\section{KONKLUZJE}

Zawarta w k.p.a. regulacja o wyłączeniu pracownika, organu i członków organu kolegialnego od udziału w postępowaniu administracyjnym (załatwienia sprawy), zwłaszcza jeśli porównamy ją z unormowaniami obcymi, musi być uznana za daleką od doskonałości ${ }^{48}$. Przetrwała ona w nieznacznie zmienionym kształcie od czasu uchwalenia kodeksu w 1960 r. Ustawodawca nie wykorzystał kolejnych, skądinąd nazbyt często przeprowadzanych nowelizacji tego aktu, do unowocześnienia tego zespołu przepisów i dostosowania go do współczesnych potrzeb. Co więcej, dopuścił się on poważnego błędu, uchylając w 1994 r. - po zaledwie kilku latach obowiązywania - art. 27a. Okoliczność ta sprawiła, że aby dochować utrwalonego w naszej tradycji standardu bezstronności orzekania przez organy jednostek samorządu terytorialnego w sprawach, w których jednostki te dysponują interesem prawnym, jako normatywną podstawę wyłączenia zaczęto wskazywać (przyznając status pracownika kierownikowi organu) art. $24 \S 1$ pkt 1 i 4 k.p.a., a jako organy umocowane do wyznaczenia organu majacego prowadzić zamiast nich postępowanie - odpowiednio samorządowe kolegia odwoławcze albo wojewodów. Za poglądem o dopuszczalności tego zabiegu opowiedziała się duża część doktryny, w mniejszym stopniu zapatrywanie to uzyskało akceptację w orzecznictwie sądów administracyjnych, co musi być traktowane jako swoiste i bardzo niepokojace „rozdwojenie jaźni”. Utrzymywanie na dłuższą metę tego stanu rzeczy, tj. posługiwanie się swoistą „protezą prawną” dla zapewnienia stanu zgodności praktyki z ogólnie uznanymi wymaganiami praworządności i sprawiedliwości proceduralnej, stwarza nieznośną sytuację prawna, burzącą nasze wyobrażenia o zasadach budowania ładu prawnego. Najprostszym rozwiązaniem rysującego się dylematu byłoby uzupełnienie przepisów art. 25 kodeksu o uregu-

48 Szerzej Kmieciak (2013): 19 n. 
lowanie stanowiące treść dawnego art. 27a, powiązane z niewielką korekta art. 26. Czas pokaże, czy ustawodawcy wystarczy odwagi i determinacji, aby zmienić te przepisy.

\author{
Zbigniew Kmieciak \\ Uniwersytet Łódzki \\ zkmieciak@wpia.uni.lodz.pl \\ https://orcid.org/0000-0002-1297-4940
}

Blake, S. (2011). Administrative Law in Canada. Markham.

Borkowski, J. (2019). Wyłączenie pracownika oraz organu, [w:] B. Adamiak, J. Borkowski, Kodeks postępowania administracyjnego. Komentarz. Warszawa: 191-237.

Brewer-Carias, A. (2009). Principios generales del procedimiento administrativo: hacia un estándar continental, [w:] C. Steiner (ed.), Procedimiento y justicia administrativa en América Latina, Mexico: 163-199.

Carroll, A. (2002). Constitutional and Administrative Law. Longman.

Chróścielewski, W. (2019). Wyłączenie pracownika oraz organu, [w:] Z. Kmieciak, W. Chróścielewski (red.), Kodeks postępowania administracyjnego. Komentarz. Warszawa: 191-220.

Garner, B.A. (ed.) (2009). Black's Law Dictionary. Thomson/West.

Gellhorn, E., Levin, R.M. (2006). Administrative Law and Process. Thomson/West.

Hauser, R., Szewczyk, M. (1996). Gmina jako strona postępowania administracyjnego - jeszcze o skutkach prawnych uchylenia art. 27a k.p.a. Samorząd Terytorialny 6(11): 45-50.

Hemmati, M., Dodds, F., Enayati, J., McHarry, J. (2002). Multi-stakeholder Processes for Governance and Sustainability: Beyond Deadlock and Conflict. London.

Iwańska, B. (2013). Koncepcja „skargi zbiorowej” w prawie ochrony środowiska. Warszawa.

Klat-Wertelecka, L. (2000). Reforma samorządu terytorialnego a kodeks postępowania administracyjnego. Samorząd Terytorialny 10(1/2): 125-142.

Klonowski, K. (2015). Wyłączenie pracownika oraz organu, [w:] H. Knysiak-Sudyka (red.), Kodeks postępowania administracyjnego. Komentarz. Warszawa: 154-177.

Kmieciak, M. (2011). Trybunały administracyjne w Zjednoczonym Królestwie (system jurysdykcji po zmianach ustawodawstwa z 2007 r.). Zeszyty Naukowe Sądownictwa Administracyjnego 3(36): $175-184$.

Kmieciak, Z. (1994). NSA: samorząd aptekarski stroną w postępowaniu administracyjnym. Edukacja Prawnicza 1(10): 242-243.

Kmieciak, Z. (2013). O ułomności regulacji prawnej wyłączenia pracownika, organu i członka organu kolegialnego od udziału w postępowaniu administracyjnym (załatwienia sprawy). Państwo i Prawo 68(11): 17-32.

Kmieciak, Z. (2014). Zarys teorii postępowania administracyjnego. Warszawa.

Kmieciak, Z. (2016). Glosa do uchwały składu 7 sędziów Naczelnego Sądu Administracyjnego z 22 września 2014 r., II GPS 1/14. Państwo i Prawo 71(6): 125-130.

Kmieciak, Z. (2017a). Glosa do wyroku Naczelnego Sądu Administracyjnego z 17 stycznia 2017 r., II OSK 968/15. Orzecznictwo Sądów Polskich 12: 75-81.

Kmieciak, Z. (2017b). Problemy i wyzwania partycypacji w postępowaniu administracyjnym, [w:] Z. Kmieciak (red.), Partycypacja w postępowaniu administracyjnym. W kierunku uspołecznienia interesu prawnego. Warszawa: 17-35.

Knysiak-Sudyka, H. (2017). Pozytywne i negatywne przesłanki właściwości organu. Instytucja wyłączenia ze sprawy, [w:] T. Woś (red.), Postępowanie administracyjne. Warszawa: 168-179.

Kubalski, G.P. (2008). Wójt jako organ orzekający w postępowaniu dotykającym interesu prawnego gminy. Samorzad Terytorialny 18(1/2): 72-85.

Künnecke, M. (2007). Tradition and Change in Administrative Law: An Anglo-American Comparison. Berlin-Heidelberg-New York.

Lemetre, F., Miranda, R. (2011). Diritto amministrativo. Napoli.

Maier, T. (2001). Befangenheit im Verwaltungsverfahren. Die Regelungen der EU-Mitgliedstaaten im Rechtsvergleich. Berlin. 
Pollitt, Ch., Bouckaert, G. (2011). Public Management Reform: A Comparative Analysis - New Public Management, Governance and the Neo-Weberian State. Oxford.

Priddat, B.P. (2008). Zur Governancealisierung der Politik: Delegation, Führung, Governance, Netzwerke, [w:] G. Schuppert, M. Zürn (Hrsg.), Governance in einer sich wandelnden Welt. Wiesbaden: 352-379.

Przybysz, P. (2017). Kodeks postępowania administracyjnego. Komentarz. Warszawa.

Rossi, G. (2011). Diritto amministrativo. Principi. Padova.

Schwarze, J. (2010). European Administrative Law. Sweet and Maxwell.

Supernat, J. (2005). Zarządzanie. Wrocław.

Suwaj, P. (2004). Gwarancje bezstronności organów administracji publicznej w postępowaniu administracyjnym. Wrocław.

Szewczyk, M. (2020). O skali normatywnej i wadze teoretycznej specustaw inwestycyjno-budowalnych oraz motywach ich stanowienia, [w:] T. Bąkowski (red.), Specustawy inwestycyjno-budowlane. Gdańsk: 81-93.

Wade, W., Forsyth, C. (2009). Administrative Law. Oxford.

Wróbel, A. (2018). Wyłączenie pracownika oraz organu, [w:] A. Wróbel, M. Jaśkowska, Kodeks postępowania administracyjnego. Komentarz. Warszawa: 230-261.

Wyrzykowski, M. (1986). Pojęcie interesu społecznego w prawie administracyjnym. Warszawa.

Zimmermann, J. (2017). Aksjomaty postępowania administracyjnego. Warszawa.

Zoller, E. (2008). Introduction to Public Law: A Comparative Study. Leiden.

\section{ON THE INCOMPATIBLE PROCEDURAL ROLES OF LOCAL SELF-GOVERNMENT BODIES}

\section{Sum mary}

The article presents an analysis of the permissibility of conducting administrative proceedings by local self-government bodies (commune heads, mayors and city presidents) in cases in which these bodies have a legal interest, that is, are treated as parties. In the author's opinion, in such cases local self-government bodies lose the ability to conduct the proceedings (are excluded from settling a case). The author takes a critical stance towards the repeal of a provision in 1994 that explicitly referred to the exclusion of these bodies. Since then, both in legal science and in judicial practice, there have been disputes as to whether such exclusion can be based on the provisions of Article $24 \S 1$ point 1 and 4 of the Code of Administrative Procedure. The author calls for a rapid amendment of the Code, supplementing Article 25 with a regulation constituting the content of Article 27a which was repealed in 1994, and making a minor revision of the existing Article 26. The question of whether the legislature has enough courage to make these changes is also addressed.

Keywords: local self-government bodies; administrative proceedings; impartiality of adjudication; exclusion of an authority from settling a case; principle of the rule of law 
